\title{
BUILDING A NEW PUBLIC IDEA ABOUT MULTILINGUALISM
}

\author{
David Gramling 1 \\ ${ }^{1}$ University of Arizona, Tucson, Arizona, United States
}

\begin{abstract}
Now nearly 20 years ago, in the wake of the 9/11 attacks and during her Presidency of the Modern Language Association of America, the Latin Americanist Mary Louise Pratt penned and published an essay on "Building a New Public Idea about Language." Looking around a linguistically diverse United States in the new twenty-first century, she asked "What's wrong with this linguistic picture?" Proposition 227 in the US State of California had all but eliminated bilingual public education in 1998, and the young people she met, whose "lives had producted strong incentives for them to learn and use other languages [than English,...] were almost entirely on their own" (111) in a country that continued to earn its nickname as a cementerio de lenguas (ibid). Pratt's prompt to academics, that we need to build "a new public idea about language" was in fact intended more expansively, as she specified further, to build a new public idea about "language, language learning, multilingualism, and citizenship" (112) and to "rediscover [...] the pleasures and pains of living multilingually" in "a country linguistically unequipped to apprehend its geopolitical situation.” (122)
\end{abstract}

Key Words: Multilingualism; Language; Translation; Public; Applied Linguistics

\section{CONSTRUINDO UMA NOVA NOÇÃO PÚBLICA SOBRE O MULTILINGUISMO}

Resumo: Há quase 20 anos, após os ataques do 11 de setembro e durante sua presidência da Modern Language Association of America, a Latino-americanista Mary Louise Pratt escreveu e publicou um artigo intitulado “Construindo uma Nova Noção Pública sobre Linguagem”. Procurando 
por um Estados Unidos linguisticamente diverso no novo século XXI, ela questionou: "O que há de errado nesse cenário linguístico?" A proposição 227 no Estado da Califórnia praticamente eliminou a educação pública bilíngue em 1998, e os jovens que ela encontrou, cujas "vidas produziam profundos incentivos para eles aprenderem e usarem outras línguas [além do Inglês, ...] estavam quase completamente por conta própria" (111) em um país que continuava a receber o apelido de cemeterio de lenguas (ibid). O lembrete de Pratt aos acadêmicos, de que nós precisávamos construir "uma nova noção sobre linguagem", foi, de fato, pretendido de forma mais abrangente, conforme ela especificou, para construir uma nova noção sobre "linguagem, aprendizado da linguagem, multilinguismo e cidadania" (112) e "redescobrir [...] os prazeres e dores de ter uma vida multilíngue" em "um país linguisticamente despreparado para apreender sua situação geopolítica" (112).

Palavras-chave: Multilinguismo; Linguagem; Tradução; Público; Linguística Aplicada

\section{Introduction}

Now nearly 20 years ago, in the wake of the $9 / 11$ attacks and during her Presidency of the Modern Language Association of America, the Latin Americanist Mary Louise Pratt penne an essay about the prospect of "Building a New Public Idea about Language." Looking around a linguistically diverse United States in the new twenty-first century, she asked "What's wrong with this linguistic picture?" Proposition 227 in the US State of California had all but eliminated bilingual public education in 1998, and the young people she met, whose "lives had produced strong incentives for them to learn and use other languages [than English,...] were almost entirely on their own" (Pratt 111) in a country that continued to earn its nickname as a cementerio de lenguas (ibid). Pratt's prompt to academics, that we need to build "a new public idea about language" was in fact intended more expansively to mean a new public idea about "language, language learning, multilingualism, and citizenship" (Pratt 112), urging us to "rediscover $[\ldots]$ the pleasures and pains of living multilingually" 
in "a country linguistically unequipped to apprehend its geopolitical situation." (Pratt 122)

Pratt's needs-analysis in 2003 was simple, elegant, and hopeful, and its substantive proposals are listed in their most succinct form later in the essay (Pratt 118). In essence, Pratt wanted US Americans, roiling in the early War on Terror as they were, to find the courage to correct a series of the nation's mythical presumptions about itself. Bilingual families, she insisted, indeed preferred for their young people to remain enduringly bilingual over their lifespans, and only discourage the maintenance of heritage languages when there is a credible fear of the implications of doing so. US Americans in general, she continued, were not hostile to multilingualism, so much as they were ambivalent; nationalist politicians had effectively fueled the negative features of that prevailing ambivalence-with little effective opposition in the public sphere from the pro-languages side. Pratt cited empirical studies showing it's never too late or too early to learn a language, and completed her overall assessment by claiming that even national security specialists want language learning curricula to encompass far more than national security concerns alone. The action items issuing from Pratt's proposal included a) urgently showing monolingualism to be a hindrance to personal and social growth, b) engaging and trusting local heritage communities, c) promoting advanced rather than shallow competence in additional languages, and establishing "linguistic pipelines" at all levels of educational preparation. This, in composite, was the "new public idea" of language that Pratt wanted us to build.

Though an occasional essay, prompted by "today's dramatic circumstances" (Pratt 112), the wisdom and practicality of Pratt's proposals have held up sturdily over the ensuing two decades. Nothing about her depiction of a "linguistically unequipped" country has been revealed inaccurate, have only deepened the importance of her, and kindred, interventions since the turn of the millennium. But, Pratt's 2003 essay was an intervention in a particular, now historical, moment. If we believe that the relationship between language and "learning, multilingualism, 
and citizenship" is historically dynamic, that it interacts quite profoundly with all manner of geopolitical contingencies and features of political economy, then twenty years-even ten, as in the case of the 2007 MLA report on Foreign Languages and Higher Education-is ample time to necessitate the reissuing of such a "new public idea".

Though Pratt's own view in 2003 was humble about the US's puzzling indextrousness about its own multilingualism, its linguaphobia or language-indifference, as it were, so has been the progress that has emerged since that call was issued. Declines in enrollments and closures of hundreds of language programs across the US indicate a broad failure to get behind Pratt's presidential vision twenty years ago. Were we simply heedless of her new public idea? Is the emerging monolingualization of "global" higher education a form of cognitive dissonance, a geopolitical strategy, or simply yet another error of foresight?

I submit that our age in languages, which I call an age of "late monolingualism" seems to be running on much more than mere linguaphobia or ideological monolingualism, in their most recognizable, controversial forms. I suggested in The Invention of Monolingualism that monolingualism as a political and economic structure is just now really getting going in earnest, particularly in its quest to individuate and then "commensurate" (Hanks) stable monolanguages in relation to one another, for the purposes of global commerce, security/surveillance, and data management. This monolingualization process, of establishing and fortifying a global grid of panfunctional, exchangeable, semantically isomorphic monolanguages can be engineered quite independently of how individual speakers actually speak and teach-and, to a certain extent too, independently of how we write. Monolingualism as an overweening supply-side enterprise can be pursued quite successfully, despite all of the visible social evidence of multilingual, translanguaging practices around us.

Of course monolingualism is no essence or entity; it has no being or substance, it has only powerful and "mythic" 
effects, in Roland Barthes sense of the word "myth." But it is nonetheless strengthening around us. Fortification, as in fortified monolingualism, is a word I began using shortly after my book on monolingualism came out in 2016 to suggest that monolingualism is not only increasing its ideological power around us, by way of overt xenophobic nationalism and linguistic racism. In the end, the "public idea" of languages that has emerged in Europe and the US since then has been a different and ambivalent one than what Pratt put forward. It is more akin to what Robert Moore identified as a "reactionary multilingualism" ascendant in European policymaking bodies. Noah Katznelson and Katie Bernsteinhave tracked this ascendency of such reactionary forms of multilingualism in US state legislative discourse, too, since 1997, in order to show how a rights-and-justice-based bilingualism discourse was rebranded over the course of the 2000s to service commercial needs first, and heritage and community needs only incidentally, if at all.

Monica Heller and Alexandre Duchene's collection from 2012 had already given an initial picture of the ideological underpinnings of such a transition from pride to profit in matters of multilingualism. Nelson Flores has also pointed out that this transformation was more or less predicted in Guadalupe Valdes' 1997 “A Cautionary Note Concerning the Education of Language-Minority Students," in which Valdes carefully predicts that bilingual immersion programs were likely going to (re-)advantage already advantaged learners, providing Anglomonolinguals ample opportunity to "do being bilingual," while increasing the likelihood that heritage bilinguals will be engaged primarily to service the learning needs of Anglo-monolinguals.

Meanwhile, ever-accelerating innovation in Cross-Linguistic Information Retrieval (CLIR) technology has brought into being a newly monetized political economy of multilingualism-one that produces translatability and translingually "controlled" meanings (Cronin) as highly valued commodities which commercial, governmental, and private consumers vie to own, fortify, and operationalize. I use the term "translatability industry" to denote 
neither the traditional translation profession (a branch that routinely uses Translation Memory, or "TM" technologies, and has done for decades without major epistemological impact on language), nor just the "Globalization, Internationalization, Localization, and Translation (GILT) industry" (Mazur \& Lako). Rather, what I am calling the "translatability industry" has, since 1990, been founded and funded upon a broader feedback loop of political economy around reactionary language management and the fortification of monolingualisms-in-translation.

The types of multilingual "knowledge engineering" (McDaniel et al.) currently underway in what I describe as the "translatability industry" take as their operative telos is not multilingualism, nor quite monolingualism, but supralingualism (Gramling (a) "Supralingualism"). While the social implications of algorithmic data-mining in multilingual online settings has become a focus of critical appraisal in recent years (see, for instance, Bagdouri et $a l$.), what has been slower to emerge are broad questions about the impact of high-quality machine translation and machine translatability on languages themselves and our public ideas about them-and therefore also on online and offline communities, as these are mediated by online algorithmic corpus-driven translation platforms. Rapidly advancing technologies of Cross-Linguistic Information Retrieval (CLIR) and Machine Translation (MT) are steadily succeeding at producing supply-side-driven compliance pathways among scores of languages (Tholpadi et al.; Saif et al.; Iwata and Katsuhiko; Dadashkarimi et al.).

Beyond academic research and industrial proprietary platforms, one of the main sources of contemporary knowledge about multilingualism is large-scale collaborations on the supranational level, whose visions of the languaged world carry so much heft as to count more as a cosmology than merely a model or framework. The 2019 Companion Volume With New Descriptors for the Common European Framework of Reference for Languages: Learning, Teaching Assessment represents a fascinating moment in the dispositive of socio-commercial multilingualism, reflecting as it 
does the preceding 20 years, since 2001 (or the past half-century, since 1964) of collaborative thought about language(s) knowledge in Europe. "Engagement in languages started," write the authors,

as a means to increase international understanding, promote lifelong learning, and increase the quality and practicality of language education in schools. It is evident that language education is fundamental to the effective enjoyment of the right to education and other individual human rights and the rights of minorities. (Council of Europe 21)

Cautious to stay out of politics, religion, and controversy of any sort, the CEFR restricts its purview to educational institutions and how they express principles of human rights for all.

What is remarkable about the array of attributes constitutive of the mood of the CEFR's multilingualism-anti-prescriptivism, universalism, holism, anti-normativity, transactive engagement, vehicularity, and success-is its profound indebtedness to the Hayekian ordoliberalism of the 1930s and onwards. Like the ordoliberal cosmology of the mid-twentieth century, these deeply optimistic and idealistic visions see absolute virtue in staving off any form of protectionism, any kind of obstruction between languages that might disempower the learner, and a deep investment in a selfregulating (linguistic) world order modeled on free-market visions.

Given the profound change in the very nature of linguistic order since Pratt's essay in 2003, I would like to reissue her call for a "new public idea" about multilingualism, based on the following proposals:

\section{The historical status of a learned multilingual elite is being filled by Artificial Intelligence.}

A tendency toward associating multilingualism with elite cultivation-over and against bilingualism as a regional and common 
phenomenon-has tended to be implicit in public usage since at least Veroboj Vildomec's work in the 1960s. The very late twentieth century was the first era in which financial exchange value was viably able to surpass use value in matters of language, and this watershed moment in the pursuit of capital through language ushered in a new commercial discourse in multilingual, translated commodities, for clients assumed or encouraged to remain monolingual for the duration of that commodity's use. As the 1980s closed, private enterprises dedicated new energies toward conceiving logistical grids of content delivery on multinational, rather than binational scales. Multilingualism as a practical principle concurrently unhinged itself from the fallacious myth of an elite class of extraordinary individual speakers, becoming rather overshadowed by the prospect of multilingualism as a technological affordance with its own burgeoning market in exchangeable values and delivery platforms.

In an age of proliferating technological platforms harnessing languages in different ways, we might wish to see this as an apparently diminished role for elite linguistic prescriptivism and deduce from that appearance that languages are more in the hands of diverse practical users of them, including of course some innovators and entrepreneurs. Savage and Williams (12) suggest, that we are dealing with a much less rosy situation, in which "capillary power" resides in its capacity to "act without the trappings of authority or public status" and are therefore "postjuridical', in the sense that [contemporary elite power] exists outside of any norms of discourse or conduct." (Davies 229) and "lacks the aspiration to act on the behalf of the public [and] elevates unconscious decisions over conscious ones." (230). The notion of an increasing "capillary power" in multilingual commodification processes smacks of centralized, intentional conspiracy, but it is in most ways a mere extension of the kind of economic theory that has prevailed in other geopolitical struggles since the mid-20 $20^{\text {th }}$ century.

In a world where language has crossed the production boundary and has become readily available for rent-seeking behaviors of various sorts, price-driven systems will wish to replace expensive, 
recalcitrant multilingual experts of various sorts with a "spontaneous coordination" among languages, in the Hayekian spirit. This spontaneous coordination takes the form of monolingualism-intranslation, and can be practiced with or without human "endusers". We must decide whether human embodied activity is central to our definition of multilingualism, and where it is that knowledge and expertise about languages lie.

\section{Pride in languages use is about defending planetary meaning resources. Semiodiversity needs to become a matter of public policy}

Now that multilingualism is no longer a field of experiential phenomena alone, but is also a trending supernational policy platform, semiodiversity-Halliday's 2002 term differentiating a diversity of "meanings" (semiodiversity) from a mere diversity of "codes" for identical meanings (glossodiversity)—should be promoted from a technical heuristic to a large-scale principle for policy, justice, and methodology. Anthropocene-oriented discourse and scholarship since 2000 have had too little to say about languages, monolingualism, multilingualism, and translation, and about the ways these have been catalytic in erecting, establishing, and maintaining industries throughout the Anthropocene period. A profound and radical change has taken place in the way 60-170 major planetary languages are coordinated to one another through supply-side algorithmic Cross-Linguistic Data Retrieval platforms and innovations, such that this kind of supralingual translatability has become a viable precondition for global commerce and industry.

\section{Multilingualism is no longer a contrary discourse}

It's puzzlingly hard these days to find a person who has something bad to say about multilingualism, and this ideological stability 
around the concept ought to make us at least a little suspicious. Even nationalists tend to find some strategic silver-lining in raising their kids to know "language of the enemy" (Pavlenko), even if they can't be asked to do so themselves. Somehow, in the past two decades, and amid the rise of predatory nationalisms, the word multilingualism has come to exude favorability, even when, from the personal and reported evidence, we suspect that the worldly experience of multilingualism-to cite Joan Didion from an altogether different context-has never been quite "a charm against snakes, something that keeps those who have it locked in some unblighted Eden, out of strange beds, ambivalent conversations, and trouble in general." (Didion n.p.) Multilingualism has never promised to come to our rescue, to solve our problems, or to keep this or that state or society well-rounded, secure, and just.

Multilingual(ism) is a designation increasingly sought and conferred by what are often acutely opposing economic, industrial, and political interests, particularly in societies where "extreme meritocracy" has become the nearly unquestioned justification for wealth disparity and crushing educational expense (Markovits). The human experience of multilingualism-honored in the work of Kramsch, Pavlenko, García, and others-today represents a shrinking market-share in what that competitive discourse around multilingual advantage highlights. Though it may grieve us to acknowledge, multilingualism is no longer just a liberating, enriching experience, or a "contrary discourse," but has become an available formula for empowerment among the already relatively powerful.

\section{The decline in language learning is a geopolitical strategy of late monolingualism}

AI (Artificial Intelligence) and Machine Translation tools, however we may appreciate their innovative power and their potential for Technology Assisted Language Learning, are also 
suppressing the desire to learn languages well and practice them in an embodied way. There is no need to blame entrepreneurs or developers for this; it is merely a profound technological shift that has put us, for the moment, in a mood around languages that is more monolingual rather than less. This period will not last forever, and in the meantime our ability to perceive and grasp the meanings that fall outside of AI algorithms is diminishing. This diminishment, in turn, goes hand-in-glove with socio-commercial pressures to globalize commodity flows along "glossodiverse" rather than "semiodiverse" lines.

\section{An unpeopled multilingualism is no multilingualism at all. Developers and consultants are affixing price/value to translatable linguistic commodities}

Over the period 1997-2016, a form fortified monolingualism has been arising in the realm of advanced algorithmic machine translation platforms that harness the power of large-scale corpora comprising real, printed language-in-use, rather than previous models that were based on rules-based machine translation. Since 1990, these so-called Cross Linguistic Information Retrieval platforms (abbreviated as CLIR) have been under extraordinarily rapid development and innovation, so as to facilitate the fast, if not immediate transfer of "data" commodities from language to language, serving transnational commercial clients in supplyside manufacture logistics. The fact that "Cross-Linguistic" in CLIR is an adjective, and that Information is the operative noun, displays the decentered and vehicular role that language is made to play in an enterprise where precisely it (and not just "data" and "information") is at the center of the means of production.

This complex multilingual process of CLIR is built however on a need for quite orderly, reliable, constituent monolingualisms or monolanguages that will work in concert in such a way in global circulation so as to not diminish revenue, slow down time-to- 
delivery, or cause expensive optimization errors for developers. Text-pre-processing strategies for CLIR include for instance "Lexicon Normalization" and "Noisy Entity Removal," procedures that Natural Language Processing (NLP) technicians may utter with a straight face, but philologists and linguists will likely have at least a few trenchant questions about.

What is particularly breathtaking about this domain of research and development (CLIR and NLP) is its bold reliance on the concept of "ontology" to give order to its various closed sets of variables in algorithmic modeling analysis (see Cross and Voss, for instance, for a forerunner). There's certainly nothing wrong with using ontology in virtual settings such as this, but to extend the concept into a notion of cross-linguistic ontology, i.e., the prospect of an operationalizable closed set of cognates across multiple languages, is a bridge too far-as the last century of anthropology, applied linguistics, translation studies, and literary theory have, in part, been dedicated to showing. Emily Apter et al.'s wonderful The Dictionary of Untranslatables, and its Frenchlanguage predecessor (Cassin et al.), helps remind us how and why languages cannot be put in any closed-set ontological relationship to one another, without cleaving off most of the most important, emic meanings that emanate from them. And yet: this kind of virtual, fuzzy ontology-building across languages is the methodological ballast for most prime-mover CLIR innovations over the past two decades. And those methodologies of course don't stay in the lab. They very quickly make their way onto all of our end-user devices, and they take up epistemic space in the patent market for languageoriented technologies.

Thanks to this new paradigm of CLIR and its commercial implementation platforms, language(s) have "crossed the production boundary" in the last two decades from non-productive to productive activity, becoming value-creating commodities in the way that financial commodities had been made to do in the 1970 s (Mazzucato). We all are now witnesses to the reckless ruin and violent wealth disparity the recategorization of financial products as 
"value-creating" has yielded between 2008 and 2019 (Appadurai). I believe a similarly tumultuous future awaits language too, now that we are no longer just commodifying language, in the pejorative sense we are accustomed to thinking commodification, but also commoditizing it - in the sense of rendering for clients predictably tradable, switchable assets for global glossodiversity management. The imprints of this quiet recategorization (and then also financialization) of language as "value-creating" in a Neoclassical economic fashion, and the consequent elevation of language engineering to a form of rent-seeking behavior, are made plain not only in these CLIR methodologies but also precisely in the legislative language by which bilingualism has been rebranded as multilingualism in the US over recent decades.

Digital media house robust creative languaging movements but, in other ways, they also abet the fortification of ideological, logistical, and commercial monolingualism-in-translation designed to propel just-in-time global manufacture. Since the 1980s, media platform engineering enterprises have found themselves responding as much to the language purist client as they have to people with "wild tongues" (Anzaldúa). The fruits of those engineers' labors have provided purists and reactionaries of various sorts as many forms of leverage as they have given translanguagers room to roam and congregate and create meaning. For every language renegade rewilding their tongue in the frontier regions of digital postmonolingualism, there is a surveillance technique innovated to ensure their suppression.

\section{Our concepts are changing quickly underneath us}

Multilingualism, monolingualism, and translation have become altogether different phenomena than they were only thirty years ago, when the first algorithmic, corpus-based machine translation platforms began their roll-out amid a financially-minded internationalist culture, often called the "Washington consensus" at the time. In its wake, no longer is monolingualism today merely a 
nationalist rallying cry, multilingualism a cosmopolitan ideal, and translation a slow artisanal practice alone. Rather, each has become part of a globally interlocking delivery modality for commercial products, linguistic and material alike. The boom in celebratory thinking about multilingualism, in and outside of academia, has as much to do with this new value-producing matrix as it ever did with shifting political ideas, post-migrational superdiversity, and the so-called decline of the ethnonational state.

I've proposed that the thirty years since 1990 - a window spanning the roll-out and refinement of algorithmic cross-linguistic information retrieval (CLIR) capacities - is a new age in language and meaning-circulation I understand as "late monolingualism". In this age, the ascendant paradigms are the supply-side management of globally translatable multilingualism through constituent prestige monolingualisms, in ways that primarily serve commercial clients, security agendas, and borderless-market stratagems, by reducing the time necessary for translation and other forms of cross-linguistic communication. Untranslatability - or what is sometimes called semiodiversity - is of course a barrier and a nuisance to these commercial purposes, and CLIR platforms accordingly aim to commensurate different languages to one another so as to produce what Yaseen Noorani calls "soft multilingualisms".

\section{Mishandling of languages is a pan-political habit. Language learning cannot be one among many tracks toward human capital acquisition in an "extreme meritocracy." Everyone needs to get a $B$ in languages}

Political campaigners from Alexandria Ocasio-Cortez to Julián Castro to Elizabeth Warren view language learning as an exercise in the cultivation of human capital. This is a notion deeply embedded in the instrumentalist code and ideolect of neoliberalism, and even the socialist candidates uphold an abstracted and alienating view of what languages are and do, what processes they are subject to, 
and what semiodiversity offers to the world. We need to lobby politicians to talk about languages in a fundamentally different way.

Though monolingualism is fortifying in new civic, legislative, and technological ways around us, this fact need not diminish the powerful insights that colleagues have provided us for decades about translanguaging, multilingual subjectivity, code-meshing, code-mixing, translingualism, multiethnolectal linguistic crossing, translation, transduction, etc. The practices that these terms seek to highlight continue to burgeon vividly and powerfully everywhere we speak, everywhere we listen. They are the real world of meaning, the real peopled ground of speaking (Lugones). And so, despite the fortifications we are tracking in monolingual procedures, it is not quite a zero-sum game we're in today, along the lines of "When monolingualism fortifies, multilingualism weakens." But it is a complex adversarial and structural relationship, and many of the fortifications of monolingualism that are underway around us are indeed designed and conceived to help obviate the need for translanguaging - and code-mixing - in socio-commercial life. They're often designed to do so in a way that does not appear to be a frontal attack on people's linguistic practices, in ways that appear assistive, predictive, unobtrusive. I wrote in the 2016 book that "Monolingualism manages other languages, it does not quite oppose them." (Gramling 11) But I do believe that radically transformative, effective, and joyous forms of real-world translanguaging will continue to flourish during this period of monolingual fortification.

\section{References}

Appadurai, Arjun. Banking on Words: The Failure of Language in the Age of Derivative Finance. Chicago: The University of Chicago Press, 2016. 
Cassin, Barbara, (Ed.). Vocabulaire européen des philosophies: Dictionnaire des intraduisibles. Paris: Le Seuil/Le Robert, 2004.

Combs, Mary Carol; Iddings, Ana Christina da Silva; Moll, Luis C. "21st Century Linguistic Apartheid: English Language Learners in Arizona Public Schools". Affirming Linguistic Diversity in Schools and Society: Beyond Linguistic Apartheid. London: Routledge, 2014.

Cronin, Michael. Translation in the Digital Age. London: Routledge, 2013.

Cross, Valerie V; Voss, Clare R. "Fuzzy Queries and Cross-Language Ontologies in Multilingual Document Exploitation." IEEE International Conference on Fuzzy Systems. 2, (2000): 641-646.

Dadashkarimi, J.; Shakery, A.; Faili, H; Zamani, H. "An expectations maximization algorithm for query translation based on pseudo-relevant documents." Information Processing and Management. 53, (2017): 371-387.

Didion, Joan. “On Self-Respect”. Vogue Magazine (1961).

Donald, Dwayne Trevor. "Forts, Curriculum, and Indigenous Métissage: Imagining Decolonization of Aboriginal-Canadian Relations in Educational Contexts". First Nations Perspectives. 2:1, (2009): 1-24.

Freire, Juan, Veronica Eileen Valdez, and Garrett Delavan. "The (Dis)inclusion of Latina/o Interests from Utah's Dual Language Education Boom". Journal of Latinos and Education. 16:4, (2017): 276-289.

Gramling, David(a). The Invention of Monolingualism. London: Bloomsbury, 2016.

Gramling, David(b). "Supralingualism and the Translatability Industry". Applied Linguistics. 41:1, (2019): 129-147.

Halliday, M.A.K. "Applied Linguistics as an Evolving Theme". Plenary address to the Association Internationale de Linguistique Appliquée. Singapore, 2002. 
Hanks, William. Converting Words: Maya in the Age of the Cross. Berkeley: University of California Press, 2010.

Iwata, T; Katsuhiko, I. "Robust unsupervised cluster matching for network data". Data Mining for Knowledge Discovery. 31, (2016): 1132-1154.

Katznelson, Noah; Bernstein, Katie. "Rebranding bilingualism: The shifting discourses of language education policy in California's 2016 election”. Linguistics and Education. 40, (2017): 11-26.

Lako, C. "On Internationalization (I18N)". Studia Universitatis Petru Maior. Philologia. 19, (2015): 151-160.

Lako, C. "Glocalization or 'looking in both directions"”. Studia Universitatis Petru Maior. Philologia. 20, (2016): 196-202.

Lugones, María. “Toward a Decolonial Feminism”. Hypatia. 25:4, (2010).

Makoni, Sinfree; Pennycook, Alastair. Disinventing and Reconstituting Languages. Bristol: Multilingual Matters, 2006.

Mazur, I. "The Metalanguage of Localization: Theory and Practice". Target: International Journal of Translation Studies. 19:2, (2007): 337-357.

Mazzucato, Mariana. The Value of Everything: Making and Taking in the Global Economy. New York: Public Affairs, 2018.

McDaniel, M.; Storey, V.; Sugumaran, V. "Assessing the quality of domain ontologies: Metrics and an automated ranking system". Data and Knowledge Engineering. 115, (2018): 32-47.

Moore, Robert. "From Revolutionary Monolingualism to Reactionary Multilingualism: Top-down Discourses of Linguistic Diversity in Europe, 1794present”. Language and Communication. 44, (2015): 19-30.

Noorani, Yaseen. "Hard and Soft Multilingualism". Critical Multilingualism Studies. 1:2, (2013): 7-28. 
Pratt, Mary Louise. "Building a New Public Idea about Language". PMLA, (2003): 110-119.

Saif, A.; Juzaiddin ab Aziz, M.; Omar, N. "Mapping Arabic WordNet synsets to Wikipedia articles using monolingual and bilingual features". Natural Language Engineering. 23:1, (2015): 53-91.

Savage, Mike; Williams, Karel. "Elites: remembered in capitalism and forgotten by social sciences”. The Sociological Review. 56:1, (2008): 1-24.

Spring, Madeline K. "The Monolingual International: Support of Language Learning through National Initiatives”. ADFL Bulletin. 43:2, (2015): 19-25.

Tholpadi, G.; Bhattacharyya, C.; Shevade, S. "Corpus-Based Translation Induction in Indian Languages: Using Auxiliary Language Corpora from Wikipedia". Transactions on Asian and Low-Resource Language Information Processing. 16:3, (2017).

Valdes, Guadalupe. "A Cautionary Note Concerning the Education of LanguageMinority Students”. Harvard Educational Review. 67:3, (1997): 391-429.

Yildiz, Yasemin. Beyond the Mother Tongue: The Postmonolingual Condition. New York: Fordham University Press, 2012.

Recebido em: 03/02/2020

Aceito em: 30/04/2020

Publicado em julho de 2020

David Gramling. E-mail: dgl@email.arizona.edu. Orcid: https://orcid.org/00000002-0027-4453. 